\title{
Proposing Additional Indicators for Indonesia Youth Development Index with Smaller Level Analysis*
}

\author{
A Case Study in South Kalimantan Province
}

\author{
Suryo Adi Rakhmawan \\ BPS-Statistics Indonesia \\ ${ }^{\ddagger}$ corresponding author: suryo.rakhmawan@bps.go.id
}

Copyright (02021 Suryo Adi Rakhmawan. This is an open-access article distributed under the Creative Commons Attribution License, which permits unrestricted use, distribution, and reproduction in any medium, provided the original work is properly cited.

\begin{abstract}
South Kalimantan is a province in Indonesia with many youths and has the lowest score in Indonesia Youth Development Index (YDI) 2017. However, the lowest score is gender and discrimination dimension which incomplete to be analysed because there are some indicators that are not included in the dimension. To solve the problems, it is necessary to build a measurement that can monitor a smaller level. Through this research, the author provides a measurement for describing the level of youth development in classifications for South Kalimantan in 2018. This index is built with the analysis factor method. It consists of five dimensions used in Indonesian YDI 2017 with some additional indicators. The result of this research shows that the index is a valid measure due to its significant correlation with Indonesia YDI 2017. The other result is the youth living in urban areas tend to have a higher index than youth who live in rural areas. While the youth who are male, also tend to have a higher development index than the female population. The suggestion for the South Kalimantan government is to improve the youth, the development priority for every classification can be started from the classification and dimension of youth index with the lowest achievement.
\end{abstract}

Keywords: factor analysis, Indonesia Youth Development Index, SUSENAS.

\footnotetext{
${ }^{*}$ Received: Jan 2021; Reviewed: Jan 2021; Published: Jun 2021
} 


\section{Introduction}

Youth development is a strategic agenda to prepare future generations who are strong and take a part in national development, and take advantage of demographic opportunities. The youth development index is an instrument to provide an overview of the progress of youth development. The Indonesian Youth Development Index in 2017 contains the achievements of 15 indicators of youth development in 2015 and 2016 as outlined in five domains namely education, health and well-being, employment and opportunity, leadership and participation, as well as gender and discrimination.

In general, the Indonesian Youth Development Index has increased from 2015 to 2016, from 47.33 percent to 50.17 percent. It shows that youth development which is one of the national goals is successful. The index was then consulted with representatives of youth organizations to obtain several inputs. One of the issues raised is that the Indonesian Youth Development Index has not given full attention to the domains and indicators that have specific targets such as marginalized youth in various aspects (gender, youth with disabilities, religious minorities, migrants, refugees, etc).

The issue of marginalized youth in various aspects needs to be included in the youth development index because it is in accordance with the slogan of sustainable development goals namely "no one left behind". Issues that are quite vulnerable to occur in Indonesia but are still hidden and many disparities in access and support are disabled. Indonesian Law No. 8 of 2016 shows that the Indonesian government should be principled to oppose discrimination against persons with disabilities as stated in the 2011 United Nations Convention on the rights of persons with disabilities.

It has been estimated that between 4 percent and 11 percent of the Indonesian population is affected by a disability that limits their ability to participate in society. This wide range in the prevalence rate arises from different surveys defining and measuring disability differently. Although there are differences in the number of people who are classified as disabled by the various surveys, there are patterns that are consistent across the various surveys. For example, people with a hearing difficulty participate more in the labor market than any other disabled group, and households with a person with a disability have lower expenditure per capita (as a measurement for income per capita).

One survey in Indonesia that can find out the prevalence of people with disabilities is Socio-Economic National Survey, or Survei Sosial Ekonomi Nasional (SUSENAS). This survey is also one of the surveys used to scoring the youth development index. With this survey, youth with disabilities can be used as an indicator in calculating the youth development index so that the index can increasingly describe youth development including marginalized youth.

The province of South Kalimantan is a province that has the lowest youth development index in Indonesia. The gender and discrimination dimensions also become dimensions with the smallest values among the other dimensions. The South Kalimantan government needs to know in more detail the measurement of the youth development index in the area mainly by including indicators of marginalized youth. Analysis at a lower level is also done to get a better picture of youth and make the government more focuses to intervene in the youth so that the steps taken can be more effective and efficient. In this research, a lower level of analysis was carried out 
by dividing youth into gender groups and the classification of urban-rural residences.

In the end, the development of youth can be monitored and prioritized on indicators that better describe the actual conditions. Moreover, the youth development index can be used to compare the development of youth with certain conditions, to capture gaps, trends, and to be a guide for governments to make the right policy for youth in South Kalimantan so as to increase their youth development index.

\section{Methods}

\subsection{Defining Youth and Youth Development}

Youth in the initial sense refers to the age group of demographics. However, these demographic age groups by institutions and organizations are defined differently. This study defines youth to adjust to the definitions used in the Indonesian Youth Development Index 2017 as stated in Indonesian Law No. 40 of 2009, namely residents with the age limit of 16-30 years.

The Commonwealth (2016a, 2016b) defines youth development as enhancing the status of young people, empowering them to build on their competencies and capabilities for life. It will enable them to contribute and benefit from a politically stable, economically viable and legally supportive environment, ensuring their full participation as active citizens in their countries. The definition shows that youth development includes various domains or dimensions that need to be adequately addressed by relevant sector policies or ministries.

\subsection{Measuring Youth Development}

The domain used in this research follows the domain that has been used in the Indonesian Youth Development Index 2017 with additional indicators obtained from the Global Youth Development Index. The additional indicator used in this research is shown in Table 1. The index is formulated to help the government, decision-makers, and stakeholders identify and learn from areas of success, pinpoint priority areas for investment, and track progress over time based on regional data. Therefore, this index uses individual data from 5 domains with indicators as below.

The importance of the indicators to be added in the index because it is important to compare the youth index in Indonesia to the other countries. The most highlighted indicator which is added in this research is access for the disability. Disability is an issue that touches many lives in Indonesia. There are at least 10 million people with some form of disability, and many of them are youth. The disabilities in Indonesia have lower educational attainment, worse health, fewer economic opportunities, and lesser access to public services than people without disabilities (Cameron \& Suarez, 2017). This indicator calculated by the youth with disabilities who can access formal education and economic opportunity (work). 
Table 1: Domains and indicators used in this research.

\begin{tabular}{|c|c|c|}
\hline No & Dimension & Indicators \\
\hline 1 & Education & $\begin{array}{l}\text { Mean years of schooling } \\
\text { Digital Natives }{ }^{\mathrm{a}} \\
\text { Literacy } \\
\text { Vocational Experience }\end{array}$ \\
\hline 2 & Health and well-being & $\begin{array}{l}\text { Smoking behaviour } \\
\text { Morbidity } \\
\text { Exercise activity } \\
\text { Frequency of consuming protein }\end{array}$ \\
\hline 3 & $\begin{array}{l}\text { Employment and } \\
\text { opportunity }\end{array}$ & $\begin{array}{l}\text { Youth in a white collar } \\
\text { Not in education, employment, or training } \\
\text { (NEET) } \\
\text { Account at a financial institution }\end{array}$ \\
\hline 4 & $\begin{array}{l}\text { Participation and } \\
\text { leadership }\end{array}$ & $\begin{array}{l}\text { Volunteering } \\
\text { Organizational participation } \\
\text { Forum participation }\end{array}$ \\
\hline 5 & Gender and discrimination & $\begin{array}{l}\text { Access for the disability } \\
\text { Child marriage } \\
\text { Access for the youth migrant }\end{array}$ \\
\hline
\end{tabular}

a new indicators

2.2.1. Calculation of scores for each indicator. The score calculation for each indicator starts from two forms of data. First is the initial data which is data from BPSStatistics Indonesia which are presented in the form of interval values. The second is transformation data, namely changes in nominal data that are changed in the form of interval data according to the level of categorization in the indicator. Furthermore, the score is obtained based on the maximum and minimum limits of each predetermined indicator. For indicators that are positive, the higher the value of the indicator, the higher the score, while the negative indicator applies otherwise. After that, the value of each indicator is normalized. Normalization used in this research is standardization (z-score).

2.2.2. Calculation of scores for each dimension. Scores in each dimension are calculated with reference to the Indonesian Youth Development Index 2017. The index of each dimension is calculated by the equal weighting.

2.2.3. Calculation of Youth Development Index. Youth Development Index is obtained by averaging each dimension score. The equal weight of each dimension means that the five dimensions have the same role to the development of youth. The use of equal weight because it can answer all arguments ethically or morally in the future about determining the more important aspects for youth development in South Kalimantan, even though in each dimension there are indicators that have the biggest role in shaping the dimension score (Bappenas, 2017). Measurement of disability in this research using Washington Group on Disability 
Statistics (WG) which is included in Socio-Economic National Survey in Indonesia. WG short set questions are not designed to measure all aspects of difficulty in functioning that people may experience, but rather those domains of functioning that are likely to identify the majority of people at risk of participation restrictions, such as difficulty seeing, hearing, walking, remembering or concentrating, self-care, and communicating.

2.2.4. Factor Analysis. Factor analysis is a statistical method used to describe variability among observed, correlated variables in terms of a potentially lower number of unobserved variables called factors (Johnson \& Wichern, 2007). In factor analysis there is random vector $X$ with $p$ component which has mean $\mu$ and covariance matrix $\Sigma$ factor model states $X$ linearly dependent with some unobserved variables which are called common factors $\left(F_{1}, F_{2}, \ldots, F_{m}\right)$, and other source of variation which is summed up as $p\left(e_{1}, e_{2}, \ldots, e_{p}\right)$ or called error or specific factor. In this research, $X$ is a variance-covariance matrix and $p(\max )$ for indicators in dimension education, health and well-being, employment and opportunity, participation and leadership, gender and discrimination are 4, 4, 3, 3 , and 3 with condition that $m \leq p . \lambda$ is the eigen value of variance-covariance matrix $\sum$ or correlation matrix $R . h_{i}{ }^{2}$ is communalities which shows the variance proportion of indicator/variable i which can be explained in general factor. While a variance which cannot be explained by general factor will be explained by a specific factor with specific variance. $\mathrm{l}_{\mathrm{ij}}$ is loading which shows a correlation between general factor formed and each indicator. The bigger $\mathrm{lij}_{\mathrm{ij}}$ means the bigger correlation between them. There are some steps in factor analysis. First, identify the purpose of using factor analysis and fulfil its requirements. Secondly, checking the correlation matrix in two ways. Bartlett test of sphericity and measuring Keiser-Meyers-Oklin (KMO) or Measure of Sampling Adequate (MSA) to assess the data appropriateness. The third step is factor extraction with methods principal component analysis. The fourth step is factor rotation, and the last is getting factors score to construct the index.

Data used in this research are from Socio-Economic National Survey Indonesia (SUSENAS) conducted by BPS-Statistics Indonesia. All the indicators used are based on the survey in 2018 so this index will capture the development of youth in 2018.

\section{Construction of Youth Development Index of South Kalimantan Province}

The selection process of indicators uses an anti-image matrix to decide whether an indicator deserves to be analysed further or not. The cut point of the MSA score is 0.5 . If the MSA score of an indicator more than 0.5 , it means that the indicator deserves to be analyzed further in factor analysis.

In the first step, indicator vocational experience and literacy in education dimension and indicator access for the youth migrant in gender and discrimination must be reduced because they have the lowest MSA which is less than 0.5 . It means that the other three dimensions have indicators that are good to be analysed without any reduction. After the indicators having MSA less than 0.5 are reduced, the education dimension and gender and discrimination dimension are good to be analysed using factor analysis. 
Factor analysis will produce dominant factors in every dimension of the index. The number of dominant factors that characterize the dimension could be decided based on the Kaiser criteria. Kaiser criteria are when factors whose eigenvalue is more than one would be the dominant factor (OECD, 2008). The factor score would be the dimension score in this research because every dimension has one factor left after rotating the component score. The dominant indicators in every dimension are mean years of schooling, morbidity, white-collar, participating on the forum, and access for the disability.

The most highlighted new indicator, access for the disability can be the most dominant indicator for gender and participation dimension. It means that access for the disability has an impact on the dimension which can reflect one of the aspects used for the government to evaluate and plan the development of youth. The reason for this finding is because disability affects some aspects of youth in developing themselves. The study from Australia-Indonesia Partnership (2017) found that youth with disabilities have lower educational attainment than others, very few youths with disabilities are studying beyond age 18. Youth with disabilities also seem to be more at risk of common health problems. Lower education and training, lower health status and limited access to services and infrastructure hamper their economic opportunities.

In this research, the analysis factor is done using transformative data (z-score), the transformative data of each individual data, and each indicator could be positive if the original data is more than the average, and could be negative If the original data is less than the average. Therefore, the composite index result could be positive, zero (if it is the same as the average), and negative. The youth with an index score of more than zero means that in the aggregate, their development index is above the national average development.

The index score with the transformative data is not easy to compare as there is no clear minimum and maximum score. Thus, the composite index score would be transformed into a cumulative probability with an approach that the distribution of the data is standardized normal (mean 0 and variance 1). This kind of transformation has been used beforehand by BPS-Statistics Indonesia in Regional Development Index. After that, the score is multiplied by 100 so the index score will be in the range $0-100$. Youth with an index score of 100 means that the youth are perfectly developed.

After all, to assess the validity of this index, it can be correlated with another valid index (OECD, 2008). In this research, the youth development index 2018 in South Kalimantan will be correlated with the South Kalimantan youth development index published by Bappenas 2017 as shown in Table 2.

Table 2: Result of correlating two indices.

\begin{tabular}{ll}
\hline & Value \\
\hline Spearman Correlation & $0.622^{*}$ \\
Sig. (2 tailed) & 0.050 \\
\hline
\end{tabular}

Based on the Table 2, the index has a strong, positive, and significant correlation. It indicates that the youth development index using factor analysis in south Kalimantan are strong and sensitive enough to capture the youth development in South Kalimantan. 


\section{Classification of Youth in South Kalimantan Province}

Classification of youth in South Kalimantan based on the youth development index is made to simplify the analysis. By far, there is no fixed method for classifying youth based on their development, but this research classifies every youth in South Kalimantan in two groups; higher and lower index.

Table 3: Odds Ratio (OR) of the dimensions.

\begin{tabular}{|c|c|c|c|c|}
\hline \multirow[t]{2}{*}{ Dimension } & \multirow[t]{2}{*}{ Classification } & \multirow[t]{2}{*}{ OR } & \multicolumn{2}{|c|}{ Cl } \\
\hline & & & Lower & Upper \\
\hline \multirow[t]{3}{*}{$\begin{array}{l}\text { Youth } \\
\text { Index }\end{array}$} & & & & \\
\hline & Rural-Urban & 0.657 & 0.529 & 0.816 \\
\hline & Female-Male & 0.747 & 0.603 & 0.924 \\
\hline \multirow[t]{3}{*}{ Education } & & & & \\
\hline & Rural-Urban & 0.346 & 0.270 & 0.444 \\
\hline & Female-Male & 0.888 & 0.812 & 0.932 \\
\hline \multicolumn{5}{|l|}{ Health and well-being } \\
\hline & Rural-Urban & 0.857 & 0.772 & 0.944 \\
\hline & Female-Male & 1.146 & 1.111 & 1.165 \\
\hline \multicolumn{5}{|l|}{ Employment and } \\
\hline & Rural-Urban & 0.812 & 0.654 & 0.974 \\
\hline & Female-Male & 0.685 & 0.553 & 0.848 \\
\hline \multirow{3}{*}{$\begin{array}{l}\text { Participation } \\
\text { leadership }\end{array}$} & & & & \\
\hline & Rural-Urban & 1.964 & 1.566 & 2.463 \\
\hline & Female-Male & 0.735 & 0.553 & 0.848 \\
\hline Gender and discrimination & Rural-Urban & 0.437 & 0.319 & 0.600 \\
\hline & Female-Male & 0.529 & 0.394 & 0.711 \\
\hline
\end{tabular}

Youth living in urban areas tend to have higher indexes than youth who live in rural areas, with an OR of 1.5 higher (Table 3). While young men who are male, also tend to have a higher development index than the female population.

If the ratio analysis is carried out on each dimension, OR for each dimension, for urban residents it will have a higher index than the rural population, except for dimension participation and leadership. The participation and leadership dimension shows that the rural population tends to have a higher development index of two times than the urban population.

Then if based on sex, the female population will have an index that tends to be higher than the male population in the health and well-being dimension. Whereas the other dimensions, the female tend to have lower indices than male. The existence of these facts indicates that the government of South Kalimantan should have a more detailed picture to build its youth according to gender and urban-rural classification. 


\section{Conclusion}

The sustainable development goals have placed youth and their role in the process of sustainable development. Many youths in South Kalimantan is a major challenge to the importance of this development, which is equal to 24.41 percent of the population. Youth development needs to be sustained by a variety of policies and data-based policies to the lowest level. The youth development index that incorporates disability indicators can be a first step towards realizing this, in line with one of the sustainable development goals that echo the jargon of leaving no one behind - including youth with disabilities. Because disability is a complex, heterogeneous phenomenon that reduces participation in education and employment, disproportionately impacts the lives, and has far-reaching consequences for affected families, but about which much remains unknown, which are have an impact on the development of the youth.

This youth development index is one way to find out more about youth development in the region. Included are classified according to house classification and gender. With this classification, the government is expected to be more accurate in determining the policies and steps to be taken.

After all, the preparation of this youth development index is only the beginning of a step that varies data on disability in Indonesia can be included in the index. Although deeper analysis needs to be done so that it will create a deeper understanding and provide a sound basis for policy aimed at increasing youth development with no one left behind.

\section{References}

[Bappenas] Bapenas, Kementerian Perencanaan Pembangunan Nasional. (2017). Indeks Pembangunan Pemuda Indonesia 2017. Jakarta (ID): Bappenas.

Commonwealth. (2016a). Global Youth Development Index and Report 2016. London (UK): The Commonwealth Secretariat.

Commonwealth. (2016b). Commonwealth Youth Development Index. National and Regional Toolkit: A Guide for Developing Regional and National Youth Development Indices. London (UK): The Commonwealth Secretariat.

Cameron, L., \& Suarez, D. C. (2017). Disability in Indonesia: What can we learn from the data?. Australian government

Johnson, R. A. \& Wichern, D. W. (2007). Applied Multivariate Statistical Analysis. New Jersey (US): Pearson Education.

[OECD] Organization for Economic Co-operation and Development. (2008). Handbook for Constructing Composite Indicators: Methodology and User Guide. Accessed in November 2018 by http://www/oecd/org/publishing. 